\title{
RESIDENT GREATER YELLOWLEGS ON THE EASTERN SHORE OF NOVA SCOTIA
}

\author{
J.A. ELLIOTT AND G.H. ELLIOTT** \\ 90 Salmon River Drive, \\ Westphal, Nova Scotia B2Z 1 HI Canada
}

\begin{abstract}
Resident Greater Yellowlegs (Tringa melanoleuca) were monitored over a five year period (2010-2014) at four sites within a selected $30 \mathrm{~km}$ by 30 $\mathrm{km}$ section on the Eastern Shore of Nova Scotia, Canada, to see if the sites are regular annual breeding territories. Three sites were occupied every year, while the fourth was only occupied in one year. There is evidence that adults arrive on site as bonded pairs, arriving as early as the third week of April, which is in advance of the peak in the seasonal continental migration. Brooding and chick rearing through May and early June enable fledging by the third week of June. Adults leave by about mid-July; juveniles have remained on site until lateAugust. Encroachment by forestry and recreational activities appears to have been accommodated by nesting pairs.
\end{abstract}

\section{INTRODUCTION}

Greater Yellowlegs (Tringa melanoleuca) are present in Nova Scotia in all seasons of the year, particularly in the coastal zone, with peak numbers during the annual migrations (e.g., Tufts, 1986, 162). They are a species that is routinely monitored throughout the Canadian Atlantic provinces by many volunteers and birders who documented their sightings in Nova Scotia Birds (nsbirdsociety.ca) and in more formal surveys such as the Atlantic Canada Shorebird Survey organized by the Canadian Wildlife Service. How many pairs establish territories and nest regularly in the province has, however, not been well studied. McLaren $(2012,102)$ gives the status for Greater Yellowlegs in Nova Scotia as follows: 'This boreal-subarctic breeder nests very sparsely here in bogs and barrens, mostly in the n.e. mainland and on Cape Breton.' As stated in The Birds of North America by Elphick and Tibbits (1998, 18 \& 10): 'The Greater and Lesser yellowlegs are among the most poorly known shorebirds in North America' and

* Authors to whom correspondence should be addressed: eljgj@eastlink.ca. 
'currently, there are few quantitative data on diet, vocalizations, territory establishment or size, sexual behaviour, nest-site selection, breeding success, nestling growth and development, dispersal, demography, migration, and so on.'

The first Maritime Atlas of Breeding Birds (Erskine, 1992), conducted from 1986-1990, recorded breeding evidence largely from the Cape Breton Highlands, with just two sightings from the Eastern Shore of the mainland for an estimated total breeding population of 'under 100 pairs'. The recent second atlas (Stewart et al, In press) replicated, in general, the results for Cape Breton, but added significantly to sightings for the Eastern Shore region, including fledged young and distraction display. The greater number of sightings for mainland Nova Scotia during the second Atlas is probably not due to a population increase but rather to better road access and, as a result, more complete surveying of the Eastern Shore.

While participating in the Second Atlas of Breeding Birds of the Maritime Provinces, we observed, on a number of occasions, Greater Yellowlegs exhibiting behaviours that would suggest local breeding. Our atlas field work was in an area approximately $30 \mathrm{~km}$ by $30 \mathrm{~km}$ at the top end of the watersheds of the East River and West River Sheet Harbour, which are located in the Eastern Shore region of mainland Nova Scotia. Based on these initial spot sightings, we undertook non-invasive monitoring (between 2010 and 2014) of four sites to see if they were regularly occupied and therefore represent annual nesting sites. The data are used to identify habitat choice, to estimate the timing of the annual nesting cycle, and to monitor for pre- and post-fledging movements. For two of the years, monitoring of the annual coastal migration was undertaken for comparison purposes.

\section{METHODS}

Fig 1 shows the distribution of freshwater wetlands for the Eastern Shore as defined by the Nova Scotia Department of Natural Resources Wetlands GIS (NSDNR, 2013). The $30 \mathrm{~km}$ by $30 \mathrm{~km}$ 'square' outlined in the Fig delimits the area we surveyed over the atlasing period 2006-2010. Almost all possible habitat for Yellowlegs was surveyed, limited in a few locations by difficulty of access. The seven 'dots' mark the sites where spot evidence of local territory was observed, including strafing, aerial displays with territorial vocalizations, and 
agitated/anxiety calls by adults. Four sites, labelled A, B, C, and D, were chosen for more detailed monitoring, with a more concentrated effort at a single site each year. Pat Lake is site A, Tent Lake is B, Belmore Flowage is C, and West Brook is D. The monitoring was intended to be weekly for the years 2010 to 2013, but was not always possible due to road conditions. For two of the sites, Pat Lake and Belmore Flowage, the regular use of a canoe made access easier and was significantly less disruptive. Monitoring of the chick rearing area was the priority, followed by stops at any known feeding areas - some of which are not on the same immediate watercourse used for chick rearing. In most cases the Yellowlegs themselves made us aware of their presence. If no initial response was seen or heard, two rounds of playback were used, based on the 'territorial' and '3-note' calls. Whenever possible, sightings were photographed to help confirm the identity of individuals. No nest hunting was done. An effort was made to minimize the impact of our presence.

Since the migrating Nova Scotia breeding population is a sub-component of the more general annual continental north-south migration, in 2011 and 2012 we explored the relative timing of spring-time arrivals and autumn departures along the coast and in the Eastern Shore nesting territories. The group of tidal mud flats found immediately east of Halifax is known to be a significant migratory stop-over for shore birds, including Yellowlegs, and these flats are a reasonable feeding/staging stop-over for territories inland along the Eastern Shore. Cole Harbour (a coastal tidal inlet located just east of Halifax) was a convenient choice. The number of Yellowlegs seen is thought to adequately capture the spring 'wave' of migrants, however the number seen on a given day at a given time can be highly variable.

\section{RESULTS}

\section{Site habitats}

The $30 \mathrm{~km}$ by $30 \mathrm{~km}$ 'square', located at the top end of the watersheds of the East River and West River Sheet Harbour, is a hilly hinterland varying in elevation between $125 \mathrm{~m}$ and $175 \mathrm{~m}$; a forested (but heavily-logged) region with patches of wetlands. It is dominantly 'upland mixed' forest. As seen in Fig 1 the percentage of area classed as wetland, i.e., the 'density' of wetlands, varies, but there is 


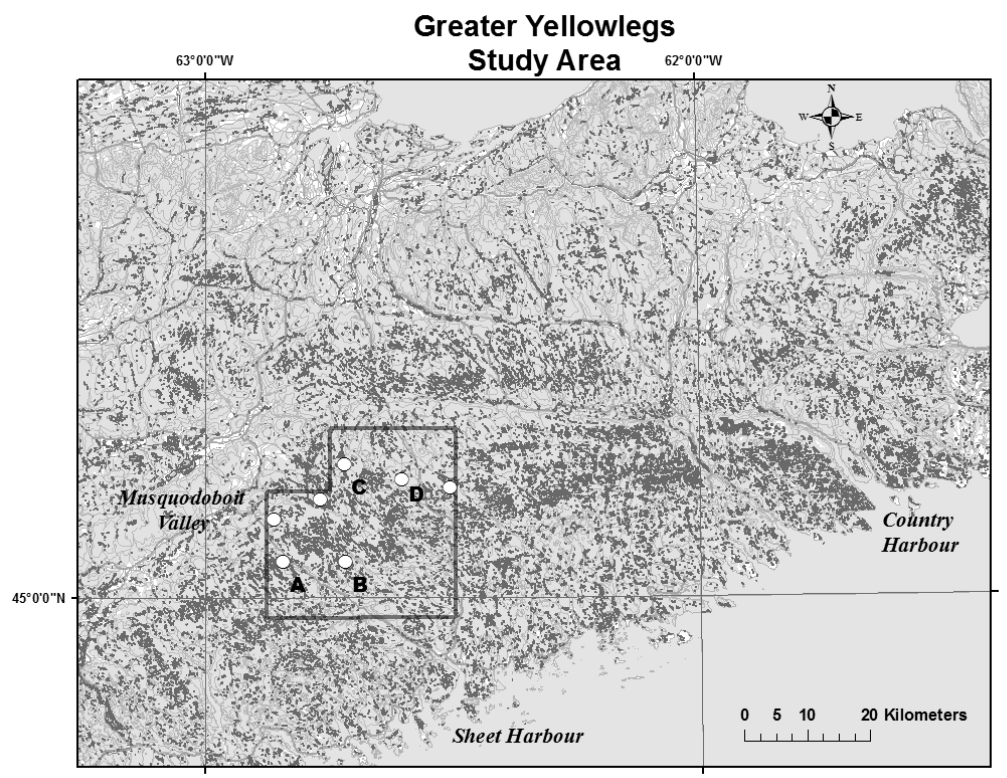

Fig 1 Eastern Shore wetlands as depicted by the merging of all freshwater Cycle3 classifications in the Nova Scotia Department of Natural Resources Wetlands Data Base. This includes, 'open bogs ', 'treed bogs' and 'wetlands general'. Our study consists of a survey of all potential territory within the $30 \mathrm{~km}$ by $30 \mathrm{~km}$ 'box'. Seven potential sites found are shown as white dots. Four, listed as A-D, were chosen for annual monitoring. The wetland data were obtained under license from the 'Nova Scotia Department of Natural Resources'.

a noticeably higher density associated with the headwater regions of the Eastern Shore rivers.

The four sites chosen for monitoring have a varied and different local mix of wetland types, but, apparently, each has a sufficient minimum habitat for nesting, for rearing of the precocial chicks through the critical first three weeks, and for dispersal of the juveniles. The habitat used for chick rearing, taken to be the most critical, is not the same wetland classification for all four sites, but all have a 'fen-like' characteristics as a dominant component; i.e. peatland (with snags or suitable trees and ground cover), a well-defined constant water course, and an associated upstream watershed limited to about one square kilometre.

For the Pat Lake site (Fig 2), the chick rearing area is the fen at the outlet of Pat Lake. Surrounding habitats are open and shrubby wetland, bogs, and a lake that includes organic mats. The Tent Lake 


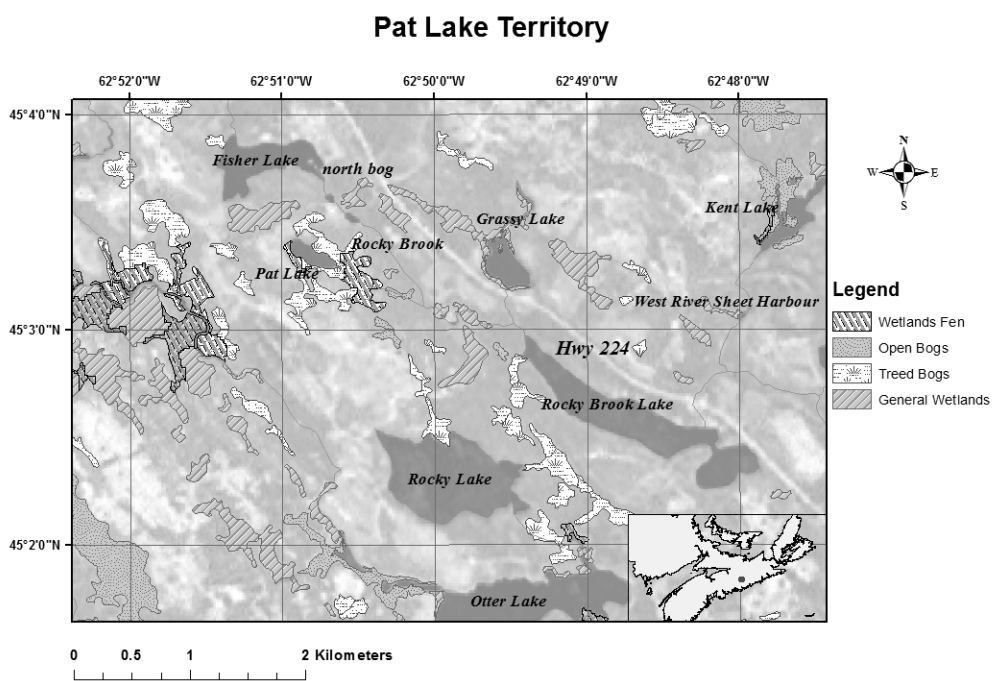

Fig 2 The Pat Lake site detail. 'Open bogs',' treed bogs', and 'general wetlands' are Cycle3 data, the 'wetlands fen' are an overlay from Cycle2. The chick rearing site is the fen at the south end of Pat Lake. Family activities were observed to range from the un-named 'north bog' to the south end of Rocky Brook Lake. The orthophoto and GIS freshwater wetlands data were obtained under license from the 'Service Nova Scotia \& Municipal Relations' and the 'Nova Scotia Department of Natural Resources'.

site chick rearing area is integrated within a complex, merged mix of swamps and bogs that together combine to flow into Tent Lake. The Belmore Flowage rearing area is located near the mouth of a small stream that empties into a shallow alcove of the Flowage margin. The broad peatland margin of this two kilometre Flowage and the nearby Grassy Lakes with extensive organic mats, are feeding areas. The West Brook site is located within one branch of the brook. It is a small watershed bordering a roughly half-kilometre circular fen. Feeding areas are in the fen and along the brook.

\section{Breeding cycle}

A summary of key observations is given in Table 1. For three of the sites (Pat Lake, Tent Lake, and Belmore Flowage) Yellowlegs have been present every year (2010-2014). At the West Brook site they were present in only two years; that site was visited on three occasions in May in 2012 and 2013 with no indication of occupation. For all the sites, the earliest on-site arrival date observed was April 20. This date is likely near the earliest date to be expected for this region, 
Table 1 Observations of the breeding cycle of Greater Yellowlegs

\begin{tabular}{|c|c|c|c|c|}
\hline & Pat Lake & Tent Lake & $\begin{array}{l}\text { Belmore } \\
\text { Flowage }\end{array}$ & West Brook \\
\hline Lat. /Long. & $\begin{array}{l}45.0534 \mathrm{~N} \\
-62.8425 \mathrm{E}\end{array}$ & $\begin{array}{l}45.0519 \mathrm{~N} \\
-62.7168 \mathrm{E}\end{array}$ & $\begin{array}{l}45.1927 \mathrm{~N} \\
-62.7167 \mathrm{E}\end{array}$ & $\begin{array}{l}45.1690 \mathrm{~N} \\
-62.6030 \mathrm{E}\end{array}$ \\
\hline Years adults on site & 2009-2014 & 2009-2014 & 2010-2014 & $2007 \&$ 2011(i) \\
\hline $\begin{array}{l}\text { Earliest date seen } \\
\text { on site }\end{array}$ & $\begin{array}{l}\text { April } 20 \\
(2011)\end{array}$ & $\begin{array}{l}\text { April } 20 \\
(2012)\end{array}$ & $\begin{array}{l}\text { April } 20 \\
(2012)\end{array}$ & $\begin{array}{l}\text { May 4(i) } \\
\text { (2011) }\end{array}$ \\
\hline \multirow[t]{7}{*}{ Chick/juvenile seen } & $\begin{array}{l}\text { July } 82009 \\
\text { (one poss. two } \\
\text { family of } 3 \text { ) }\end{array}$ & $\begin{array}{l}\text { July } 202011 \\
\text { (two feeding } \\
\text { together) }\end{array}$ & $\begin{array}{l}\text { June } 62013 \\
\text { (one with } \\
\text { adults) }\end{array}$ & \\
\hline & $\begin{array}{l}\text { July } 82010 \\
\text { (three with } \\
\text { adults) }\end{array}$ & $\begin{array}{l}\text { Aug } 12013 \\
\text { (one) }\end{array}$ & $\begin{array}{l}\text { Aug } 152013 \\
\text { (one) }\end{array}$ & \\
\hline & $\begin{array}{l}\text { July } 92009 \\
\text { (one) }\end{array}$ & $\begin{array}{l}\text { July } 92014 \\
\text { (one with adult) }\end{array}$ & & \\
\hline & $\begin{array}{l}\text { July } 152009 \\
\text { (three with } \\
\text { adults) }\end{array}$ & & & \\
\hline & $\begin{array}{l}\text { July } 152010 \\
\text { (one) }\end{array}$ & & & \\
\hline & $\begin{array}{l}\text { July } 192011 \\
\text { (one) }\end{array}$ & & & \\
\hline & $\begin{array}{l}\text { Aug } 152013 \\
\text { (one) }\end{array}$ & & & \\
\hline $\begin{array}{l}\text { Last date family } \\
\text { group seen }\end{array}$ & July 15 (2009) & & & \\
\hline
\end{tabular}

Note: (i) Site surveyed in 2012 and 2013. May 4 earliest date surveyed.

as lake and stream margins are often frozen through early April. No Yellowlegs were seen on frequent trips to Pat Lake in the first half of April for any year regardless of weather and none were present at Belmore Flowage by April 21, 2014.

The timing of the breeding cycle can be bracketed from the combined data. Juveniles were transiting between the rearing location and nearby (approx. $1 \mathrm{~km}$ ) feeding areas by June 30 (2010) for Pat Lake and June 20 (2013) for Belmore Flowage. Actual dates for fledging could be earlier by up to one and a half weeks for Pat Lake and one week for Belmore Flowage given our sampling interval. However, from our estimated age of the young seen at Belmore Flowage on 
June 6, 2013, the June 20 date is thought to be near first flight. Using the nominal times required for incubation and for hatched precocial chicks to develop fluttering flight as 23 days and 25 days respectively (Elphick and Tibbits, 1998), our data suggest typical dates as: earliest arrival within the last weeks of April, incubation started by the end of first week of May, hatching near end of May (23 days), fledging by third week of June ( 25 days), and moving amongst prime feeding areas through July/August. In 2011, at Belmore Flowage, territorial competition between males was underway on May 3, in line with the above.

Also, as seen in Table 1, are the dates when young were seen at the four sites. Although observed, we have not tabled occasions when we thought females were vocally instructing hidden young. Young with adults were seen up until mid-July. Young were present at two sites until mid-August in 2013. The Pat Lake location, frequently used by juveniles, appeared to be abandoned much earlier in 2010. That year over $11 \mathrm{~cm}$ of rain occurred between July 12 and 15; Pat Lake levels rose by about $20 \mathrm{~cm}$ and local flooding was evident for some streams. No evidence of individuals at any of the usual feeding sites was found in the days following. Thus weather, including a heavy rain event, may influence the time of final departure.

\section{Feeding activities}

Because of our limited spatial and temporal coverage, these data do not reveal every feeding location or the outer boundaries of a defended territory. However, the Belmore Flowage, which is about two kilometres long with diverse shoreline habitat and with a chick rearing site at midway, appears to be the extent of occupied territory and feeding areas from first arrival in April to fledged young. Territorial competition (May 3, 2011) ended when the interlopers left the Flowage. On all occasions two adults were seen feeding during the pre-brooding phase and at least one during brooding. During brooding the male was seen and occasionally the female would be seen or heard. After hatching the female and 'young' remained within about a half kilometre of their small embayment. In this phase the male was present, often vocal, with occasional strafing. After fledging, the family used both the flowage and the Grassy Lakes, two kilometres upstream, as feeding areas.

Pat Lake and Tent Lake had a similar pattern. At Pat Lake, pre-hatching, the male maintained a mostly silent vigil near the 


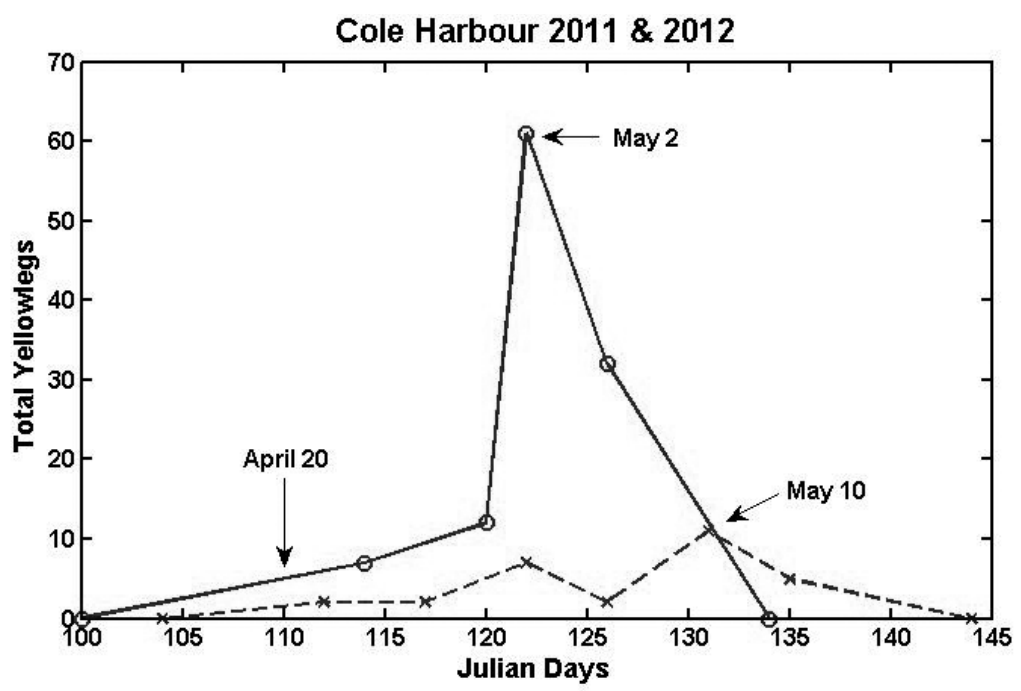

Fig 3 Dates of arrival of Yellowlegs 'on territory' on the Eastern Shore, April 20, relative to the occurrence of migrating Yellowlegs as seen passing through at the Cole Harbour tidal flats in 2011 ' 0 ' and 2012 ' $x$ '. One adult was 'on territory' on April 20 in 2011, which is Julian date 110, and three in 2012, Julian date 111. In both years the Eastern Shore 'on territory' arrivals are at the leading edge of the annual spring migration.

rearing fen. After hatching the female remained within the fen area. After fledging, family activity, with 'family chatter', was observed from the 'north bog' to the south end of Rocky Brook Lake, Fig 2. For Tent Lake all sightings were within the fen/bog/swamp complex, a domain of about one and a half kilometres diameter.

\section{Migration}

Eastern Shore Greater Yellowlegs are early spring arrivals. When we compared arrival dates on territory to the passing coastal migration, the Eastern Shore population is seen to be arriving on the leading edge. The comparison, undertaken in 2011 and 2012, is shown in Fig 3 . The year 2011 was locally considered as a 'late spring' associated with foggy/rainy weather, while 2012 was an 'early spring' with open water on lakes by late March. In both years, Yellowlegs were seen on territory by April 20. This date coincides with the earliest arrivals seen on the coast (Cole Harbour).

In addition to being 'early' arrivals, there is evidence that Yellowlegs are migrating and arriving on site as mated pairs: 1) on April 20, 
2012, an early arrival pair of Yellowlegs at Tent Lake gave territorial calls and display, 2) on each of two occasions, well in advance of the arrival of the main migration, a pair of Yellowlegs in migration were feeding together at Cole Harbour (April 21, and 26, 2012), 3) at Cole Harbour on May 1, 2012, a bonded pair used the joint three- or four-second volley of the 3 note calls followed by the male giving a roughly four-second round of territorial call, calls identical to those used by a pair arriving on April 20 at Tent Lake, and 4) on May 3, 2011, two pairs of Yellowlegs were in serious competition for territory at Belmore Flowage.

Dispersal of the families from the nesting sites in mid-July is characterized by fewer adults and single juveniles scattered at various territorial feeding sites. Latest dates for inland family groups is about mid-July, and for juveniles, mid-August. This coincides with the appearance of more individuals, adults then young, at the 'local' coastal tidal flats.

\section{DISCUSSION}

Our observations that Yellowlegs are arriving on site as bonded pairs is similar to the behaviour of a closely related species, the Greenshank (Tringa nebularia). The Greenshank has migration/territory in northern Scotland similar to the terrain of Nova Scotia. In Scotland the prominent local, migration feeding areas are in 'particular bays and inlets of a firth or a larger loch' at a convenient distance from the nesting/ rearing sites (Nethersole-Thompson and Nethersole-Thompson, 1979, 101ff.). It is thought that these areas also serve as 'mating territories' where 'mating' occurs or 'pairs re-mate'. A similar pattern would fit our Nova Scotia observations. The coastal mud flats (not restricted to the group immediately east of Halifax) would be suitable, prominent, and identifiable mating territories. These are the only obvious common gathering points for the Eastern Shore. Located along the natural migration route north, they would be familiar territory as they are a major initial autumn feeding stop-over.

The regular annual occupation of the nesting/rearing sites suggests that this region of the Eastern Shore has the necessary mix of suitable habitat. As shown in Fig 2, the wetlands near Pat Lake are a mix of habitat classifications and are not particularly extensive; some are patches no more than a few hectares, or margins less than $100 \mathrm{~m}$ wide. 
The other three sites monitored are equally compact and diverse. The Wetland Inventory on the Nova Scotia Department of Natural Resources website (NSDNR, 2013) shows a similar mix of habitat classification and density throughout the higher wetland 'densities' as shown in Fig 1. Thus potential territories could extend along the entire inland region of the Eastern Shore from east of the Musquodoboit Valley, including the watershed of the West River St. Mary's, down to the coast at Country Harbour, a length of approximately $120 \mathrm{~km}$. It is within this region where most of the mainland Yellowlegs were recorded in the Second Atlas. The distance between the nesting sites in our study varies between 7 and 15 kilometres, or roughly $10 \mathrm{~km}$. This breeding density number is similar to the lower numbers seen for northern breeding populations: the lowest population density seen in the Ontario atlas (Cadman et al, 1987) is about one per 10 $\mathrm{km}$ square. For this nesting density the Eastern Shore has sufficient wetland for at least 30 pairs.

The Pat Lake and Tent Lake sites provide examples of accommodation to increased human encroachment. The first atlas (Erskine, 1992) recorded a Yellowlegs confirmation near Pat Lake. Since the first atlas clear-cut logging continues, cottage country has expanded, and fishermen are more numerous. Family cottages are now at the edge of the Rocky Brook Lake feeding area. Clear cutting of the forest on all sides of the nesting, rearing and feeding areas has taken place. Recently, tree harvesters worked through June and July, 2011, to within $10 \mathrm{~m}$ along the edge of the rearing/nesting site for what was a successful breeding year. At the Tent Lake site a major haul road cuts through the breeding wetland complex, yet adults and young still feed roadside. The same forestry practices apply to the other sites, and yet the Yellowlegs persist.

Acknowledgements We thank the reviewers for their guidance and Eric Mills who encouraged us to prepare this paper and provided advice throughout the early stages. Support was received from Pierre Clement, Dept. of Fisheries and Oceans, Bedford Institute of Oceanography, in preparation of GIS material. Finally, we appreciate the inspiration and the challenge given to Canadians by Desmond and Maimie in their book 'Greenshanks'; in the closing pages they encouraged further work on Greater Yellowlegs: 'We have one great disappointment. It would have been splendid to compare notes on the 
breeding behaviour and ecology of the greater yellowlegs and thus achieve a better understanding of two wonderful birds.'(NethersoleThompson and Nethersole-Thompson, 1979, 214).

\section{REFERENCES}

Cadman, M.D., Eagles, P.F.J., \& Helleiner, F.M. (1987). Atlas of the breeding birds of Ontario. Univ. of Waterloo Press, Waterloo, ON.

Elphick, C.S., \& Tibbets, T.L. (1998). Greater Yellowlegs. The Birds of North America, No. 355.

Erskine, A.J. (1992). Atlas of Breeding Birds of the Maritime Provinces. Nova Scotia Museum, Halifax, N.S.

McLaren, I.A. (2012). All the Birds of Nova Scotia. Gaspereau Press, Kentville, N.S.

Nethersole-Thompson, D., \& Nethersole-Thompson, M. (1979). Greenshanks. T\&AD Poyser, Berkhamsted, UK.

Nova Scotia Department of Natural Resources. (2013). Wetland Inventory. http://novascotia.ca/natr/wildlife/habitats/wetlands.asp [accessed August 2014].

Stewart, R.L.M., Bredin, K.A., Couturier, A., Horn, A.G., Lepage, D., Makepeace, S., Taylor, P.D., Villard, M.A., and Whittam, R.M., eds., (In press). Second Atlas of Breeding Birds of the Maritime Provinces. Bird Studies Canada, Environment Canada, Natural History Society of Prince Edward Island, Nature New Brunswick, New Brunswick Department of Natural Resources, Nova Scotia Bird Society, Nova Scotia Department of Natural Resources, and Prince Edward Island Department of Agriculture and Forestry, Sackville, New Brunswick.

Tufts, R.W. (1986). Birds of Nova Scotia. Third Edition, Nova Scotia Museum, Halifax, N.S. 
